\title{
THREATENING DYSTOPIAS
}




\section{A Volume in the Series}

Cornell Series on Land: New Perspectives in Territory, Development, and Environment

Edited by Wendy Wolford, Nancy Peluso, and Michael Goldman

A list of titles in this series is available at cornellpress.cornell.edu. 


\section{THREATENING DYSTOPIAS}

The Global Politics of Climate Change Adaptation in Bangladesh

Kasia Paprocki 


\section{Copyright ( 2021 by Cornell University}

All rights reserved. Except for brief quotations in a review, this book, or parts thereof, must not be reproduced in any form without permission in writing from the publisher. For information, address Cornell University Press, Sage House, 512 East State Street, Ithaca, New York 14850. Visit our website at cornellpress.cornell.edu.

First published 2021 by Cornell University Press

\section{Library of Congress Cataloging-in-Publication Data}

Names: Paprocki, Kasia, author.

Title: Threatening dystopias: the global politics of climate change adaptation in Bangladesh / Kasia Paprocki.

Description: Ithaca [New York] : Cornell University Press, 2021. | Series: Cornell series on land: new perspectives in territory, development, and environment | Includes bibliographical references and index.

Identifiers: LCCN 2021011479 (print) | LCCN 2021011480 (ebook) | ISBN 9781501759154 (hardcover) | ISBN 9781501759161 (paperback) | ISBN 9781501759178 (pdf) | ISBN 9781501759185 (epub)

Subjects: LCSH: Climatic changes—Political aspects—Bangladesh. | Climatic changes-Economic aspects-Bangladesh. | Climatic changes-Social aspects-Bangladesh. | Climatic changes-Political aspects. | Climatic changesEconomic aspects. | Climatic changes-Social aspects.

Classification: LCC QC903.2.B3 P37 2021 (print) | LCC QC903.2.B3 (ebook) | DDC 363.738/74561095492-dc23

LC record available at https://lccn.loc.gov/2021011479

LC ebook record available at https://lccn.loc.gov/2021011480 
To the memories of Karunamoyee Sardar and Xulhaz Mannan, and to the brave activists who honor them by continuing their struggles 
